39 years. She died in her Atlanta home on February 8, 2008, after a short illness. Eleanor received a BA from Hunter College in 1963 and a Ph.D. in political science from the University of North Carolina at Chapel Hill in 1966. After a post-doctoral fellowship at the University of Texas, Austin, she accepted her first tenure-track position at the University of Connecticut. Just two years later she joined the political science department at Emory University.

Eleanor specialized in American politics, with particular interests in urban politics and public policy. Her work always focused on the ways in which government could better assist people.

During the 1970s, for example, she did pioneering research evaluating the effectiveness of the federal Model Cities Program, examining the delivery of social services to needy homemakers, and exploring the attitudes of county welfare administrators. Later, she published work on the treatment of women by legislatures and courts. During the 1980s, Eleanor was the associate editor of the Journal of Politics. Throughout her life she remained fascinated with the way in which politics works at the local level with a special focus on the politics of education administration.

When Eleanor came to Emory in 1969, she very quickly became the glue that held a small and very young group of faculty together, particularly after one of our only two senior faculty members left. Like a mother hen she reassured the nine untenured males that we were following the right procedures, publishing in the right journals, telling the students what they needed to do and know, and that we were making the right decisions about our careers and the department. Nearly everyone went to her for advice and guidance, not only about professional, but also about personal matters. It seemed that she was always in the office and always available to talk.

And it was not only faculty who beat a path to her door. Graduate students, undergraduates, staff, and custodians were constant visitors. Eleanor was never too busy to listen to a complaint or a worry. And, she quietly helped those who needed help. Several of the janitorial staff came to her regularly for assistance when they could not make ends meet or faced family emergencies. Students in crisis could always count on Eleanor to come to their aid. Such charitable acts were always done privately with no expectation of fanfare or even repayment.

Eleanor's love for people extended to her devotion to her university. She delighted in finding solutions to institutional problems and implementing them.
Immediately after arriving at Emory, she established the first internship program in the college and was influential in creating the State of Georgia Legislative Internship Program, which she headed for 13 years. She originated a track for especially talented undergraduates that allowed them to earn a bachelors and a masters degree in four years. She was instrumental in conceiving and inaugurating an innovative initiative to train graduate students from all disciplines in how to be effective undergraduate teachers.

Eleanor's talents were soon recognized by Emory's administrators who repeatedly lured her away from her teaching and research activities to assume leadership positions. She first served as chair of the political science department and then went on to an uninterrupted string of administrative assignments: associate dean of Emory College, acting dean of Emory College, associate dean of the graduate school, interim dean of the graduate school, and associate provost for graduate studies. In 2001 the university, taking advantage of her expertise in education policy, persuaded Eleanor to lead the Division of Educational Studies, a post she held until her untimely death. Throughout her years at Emory Eleanor served on nearly every important university committee and task force. There was almost no campus initiative that did not bear her fingerprints. In effect, Eleanor became the university's first option when difficult or emergency administrative problems arose. She never shied away from a challenge and she never disappointed. In recognition of her contributions, in 2003 Emory bestowed upon her the Thomas Jefferson Award, its highest tribute for distinguished service and leadership.

Eleanor's administrative prowess was recognized well beyond the boundaries of Emory's campus. Three Georgia governors appointed her to various state departments and commissions. These included such diverse agencies as the Department of Juvenile Justice, the Professional Standards Evaluation Panel, the Committee to Evaluate the State Formula for Education Funding, the Governor's Commission on Effectiveness and Economy in Government, and the Governor's Task Force on Teacher Pay for Performance. These service contributions reflected once again Eleanor's commitment to the goal of making government more responsive to the needs of people.

Eleanor's accomplishments led to several employment offers, including highranking state administrative offices and leadership positions at other colleges and universities. While flattered by these opportunities, Eleanor had little interest in higher positions that would involve more bureaucracy and less contact with people. Because of her love for Emory University, she remained a member of the faculty for the rest of her career. In typical Eleanor Main fashion, she spent her final years devoted to Emory's Challenges and Champions program, an initiative to provide special training for junior high school students in academics, health, and physical fitness.

Eleanor was never one to pull her punches. She told students, colleagues, and administrators what they needed to hear, not what they wanted to hear. Her refreshing honesty and straight talk ensured that her counsel was widely sought and often followed. Her premature death is a great loss for Emory and all of those who treasured her. In her honor, The Eleanor Main Endowment at Emory is being established to support graduate student research and the Challenges and Champions program.

Harvey E. Klehr
Emory University
Thomas G. Walker
Emory University

\section{Calvin Miller}

\section{Gary Baker's Tribute}

On Tuesday, December 4, 2007, Dr. Calvin Miller passed. Dr. Calvin M. Miller, a political scientist and practitioner of politics for most of his life, helped shape his students' understanding of civil rights, grassroots politics, government, and elections as a professor and former chairman of Virginia State University's political science department. It was because of his commitment to teaching, community activism, and nurturing of students that he gained the respect of students, colleagues, and administrators.

Among the students that he greatly influenced was Roger L. Gregory. Justice Roger L. Gregory is the only African American to serve on the United States Court of Appeals for the Fourth Circuit. This appointment is historic. The Fourth Circuit, which hears appeals from trial courts in Maryland, North Carolina, South Carolina, Virginia, and West Virginia, has the largest African-American population of any circuit in this country, yet it had never had an AfricanAmerican appellate judge.

Dr. Miller was also teacher and mentor to the current United States ambassador to Ghana, Ambassador Pamela Bridgewater. Prior to her ambassadorship in Ghana, Ambassador Bridgewater was 
the longest serving U.S. diplomat in South Africa.

While at Virginia State University, Dr. Miller also served as dean of the School of Liberal Arts and Education before his retirement in 1992. "He was very dedicated to educating his students about civil rights and exposing them to the larger world culture," said his daughter, Zanda M. Miller of Chester, who helps dropouts and ex-felons gain career training through the Petersburg-based Pathways program.

Dr. Miller was born in 1924 in rigidly segregated Bessemer, Alabama. After graduating from high school he enrolled at Morehouse College, Atlanta, Georgia, in 1942. In 1944 his education was placed on hold when he was drafted into the army during World War II. After his discharge, he returned to Morehouse College and completed his bachelors degree. After graduating from Morehouse College he moved to New York and began work at the United Nations while earning his masters degree in political science from the New School for Social Research, and would later earn his doctorate from Lehigh University in Pennsylvania. Dr. Miller was an active participant in the activities of the NAACP and the Southern Christian Leadership Conference during the civil rights era, and took part in several major demonstrations, including the 1965 march for voting rights in Selma, Alabama.

Dr. Miller began his teaching career in political science in 1962 at Tuskegee Institute. He also taught classes at Jackson State University before joining the Virginia State University faculty. When he retired from Virginia State University, he returned to Jackson State where he continued to teach until 1997 when he ended his 35-year career in academe.

Dr. Miller's first wife, D. Antoinette Handy-Miller, was a renowned jazz flutist and jazz historian who also taught music at Virginia State University. She later directed the Music Grants Program for the National Endowment for the Arts, Washington, D.C., where she helped establish a national jazz support group. The Millers were married for 43 years. D. Antoinette Handy-Miller passed in 2002.

Dr. Miller's survivors include two sons, Talbot B. Miller of Jackson, Mississippi, and Uzoma O. Miller of Nashville; two brothers, Alfred D. Miller and Sandy L. Miller, both of Birmingham; a sister, Winifred Crawford of Nashville; and eight grandchildren and three great-grandchildren.

Dr. Miller's legacy of teaching, commitment to the community, and activism will continue in the generation of stu-

dents whose lives he has touched, and changed.

Gary Baker

Virginia State University

\section{Lisa Nikol Nealy's Tribute}

Dr. Calvin Miller passed away in Nashville, Tennessee, on December 4, 2007. A retired professor of political science at Jackson State University and former chairman of Virginia State University for 26 years had a monumental impact on students of all nationalities. I am so honored and blessed to have known Dr. Calvin Miller as his undergraduate and graduate student at Jackson State University. Dr. Miller served as a thesis advisor on my masters thesis committee at Jackson State University. Miller strongly encouraged me to publish my thesis entitled "Prisoner's Deaths in Local Jails: Factors Influencing Inmate Suicide" and in 2004, it was published.

I became to know Dr. Miller extremely well as a thought-provoking scholar who wasn't timid about pontificating on issues affecting the African-American community. But most of all, I grew to love him as a person who was deeply committed, dedicated, and rooted in advancing the African-American race collectively. Dr. Miller truly impacted my personal, intellectual, and professional development as a student of politics, and now, a professor of politics. As one of his graduate students, I specifically remember engaging in very intense and vigorous intellectual discussions with Dr. Miller concerning issues facing the African-American community. These exchanges of intellectual ideas occurred not only in the classroom, but outside of the classroom as well. Dr. Miller was deeply perplexed with the proliferation rate of young AfricanAmerican males becoming incarcerated in America's industrial prison complex.

Miller also influenced other students as well such as Federal Appeals Court Judge Roger L. Gregory of Richmond. Dr. Miller helped shape his students' understanding of civil rights, government, and elections as a professor and chairman of the Virginia State University's political science department. Dr. Miller also served a stint as dean of VSU's School of Liberal Arts and Education before he retired in 1992 from the Petersburg-area school. "He was very dedicated to educating his students about civil rights and exposing them to the larger world culture," said his daughter, Zanda M. Miller of Chester, who helps dropouts and ex-felons gain career training through the Petersburg-based Pathways program. He also was very active in politics. While at VSU, he often made community appearances, making observations from a civil rights perspective, while passionately urging black people to get politically involved to gain empowerment. A native of Bessemer, Alabama, he participated in the NAACP and the Southern Christian Leadership Conference during the civil rights era and took part in several major demonstrations, including the 1965 march for voting rights in Selma, Alabama, Ms. Miller said. During his tenure at Virginia State, he also ran, though unsuccessfully, for a seat on the Hopewell City Council.

Born in 1924 in rigidly segregated Alabama, Dr. Miller persevered, graduating from high school and entering Morehouse College in 1942. He was drafted into the army in 1944 during World War II. After his discharge, he completed his degree at Morehouse and then moved to New York. He worked at the United Nations while earning his masters in political science from the New School for Social Research. He later earned his doctorate from Lehigh University in Pennsylvania. He began teaching political science in 1962 at Tuskegee Institute in his home state. He also taught at Jackson State University before joining the VSU faculty. When he left VSU, he returned to Jackson State where he continued to teach until 1997 when he ended his 35-year career in academe. His first wife, D. Antoinette Handy-Miller, was a renowned jazz flutist and jazz historian who also taught music at VSU. She later directed the music grants program for the National Endowment for the Arts, where she helped establish a national jazz support group. She died in 2002. The Millers were married 43 years. In 2006, Dr. Miller married again. His second wife, Jeanette Miller, died last April. Other survivors include two sons, Talbot B. Miller of Jackson, Mississippi, and Uzoma O. Miller of Nashville; two brothers, Alfred D. Miller and Sandy L. Miller, both of Birmingham, Alabama; a sister, Winifred Crawford of Nashville; and eight grandchildren and three great-grandchildren.

Dr. Miller died in Nashville, Tennessee, where he had moved eight months ago to be nearer to a son and his sister. He was 83 . The family held a memorial service for him in Nashville on Saturday, December 8, 2007. At his request, his body was donated to Meharry Medical College.

Miller was a very unique individual who had a way with words and never vacillated on his views. He shall indeed be missed, but his legacy lives on.

Lisa Nikol Nealy Clark-Atlanta University 